\title{
Peningkatan Keterampilan Menulis Narasi melalui Model Pembelajaran SAVI Berbantuan Media CD Interaktif
}

\author{
Ayu Vidya Rakhmawati ${ }^{1}$, Supriyono Koeshandayanto ${ }^{2}$, Muhana Gipayana ${ }^{3}$ \\ ${ }^{1}$ Pendidikan Dasar-Universitas Negeri Malang \\ ${ }^{2}$ Pendidikan Fisika-Universitas Negeri Malang \\ ${ }^{3}$ Pendidikan Guru Sekolah Dasar-Universitas Negeri Malang
}

\section{INFO ARTIKEL}

Riwayat Artikel:

Diterima: 07-12-2018

Disetujui: 17-01-2019
\end{abstract}

\section{Kata kunci: \\ writing narrative; SAVI learning model; media $C D$ interactive menulis narasi; model pembelajaran SAVI; media CD interaktif}

\author{
Alamat Korespondensi: \\ Ayu Vidya Rakhmawati \\ Pendidikan Dasar \\ Universitas Negeri Malang \\ Jalan Semarang 5 Malang \\ E-mail: ayufira31@gmail.com
}

Proses pembelajaran berbahasa guna meningkatkan keterampilan siswa dalam berbahasa Indonesia perlu diperhatikan oleh guru. Melihat pentingnya berbahasa Indonesia, maka melalui pembelajaran bahasa Indonesia para siswa diharapkan dapat mengaplikasikan dalam kehidupan sehari-hari sehingga siswa tidak hanya mengetahui teori tentang bahasa saja. Hal itu sesuai dengan empat aspek keterampilan berbahasa, yaitu mendengar, membaca, menulis, dan berbicara (Mudiono, 2010). Murcia \& Olshtain (2000) menyatakan bahwa menulis adalah kegiatan yang dapat menghasilkan kata-kata tertulis yang terbentuk dalam sebuah teks. Menurut Gipayana (2004) berpendapat bahwa pelajaran menulis di SD bertujuan untuk (1) sarana penyampaian informasi secara tertulis berdasarkan pengalaman yang dialaminya; (2) menyalurkan bakat menulis; (3) sarana untuk mengembangkan ide, gagasan, pendapat, pesan informasi; (4) menjadikan menulis sebagai karya dalam mata pelajaran bahasa Indonesia. Keterampilan menulis narasi merupakan sebuah keterampilan siswa dalam membuat cerita yang didalamnya terdapat beberapa unsur yaitu, tema, tokoh, alur, latar, sudut pandang, dan amanat dalam suatu rangkaian peristiwa. Untuk membuat sebuah cerita tersebut dibutuhkan penguasaan keterampilan menulis narasi yang baik, tetapi hal ini tidak sejalan dengan kenyataannya di lapangan bahwa siswa masih kesulitan untuk menguasai keterampilan menulis narasi dengan baik (Yafi, Santoso \& Mudiono, 2017).

Kesulitan untuk menguasai keterampilan menulis narasi yang baik tersebut didukung dengan penelitian sebelumnya yang dilakukan oleh (Wulandari, 2014) menyatakan bahwa menulis merupakan keterampilan yang dianggap sulit oleh beberapa siswa. Aspek menulislah yang sering ditakuti oleh siswa dari keempat aspek keterampilan berbahasa. Dalam pembelajaran menulis banyak dijumpai siswa yang cenderung merasa bosan. Rasa bosan yang dialami oleh siswa itu menyebabkan situasi belajar kurang kondusif dan siswa menjadi malas belajar menulis narasi sehingga apresiasi dan keaktifan siswa di dalam kegiatan menulis narasi sangat kurang. Penggunaan model dan media pembelajaran yang kurang kreatif dan inovatif merupakan salah satu penyebab terjadinya pembelajaran yang kurang kondusif sehingga menimbulkan rasa bosan pada siswa. 
Berdasarkan pegamatan di lapangan yang dilakukan di SD Anak Saleh terhadap siswa kelas V pada tanggal 27 Maret 2018 mengenai keterampilan menulis narasi ditemukan hasil bahwa keterampilan siswa dalam menulis narasi masih sangat rendah. Hal tersebut ditunjukkan dengan 20 dari 28 siswa hasil menulis cerita narasi tentang pengalaman pribadi mereka masih belum memenuhi Kriteria Ketuntasan Minimal yaitu 70. Serta terdapat tiga siswa yang memiliki hasil menulis karangan narasinya yaitu 70. Permasalahan yang muncul saat pembelajaran menulis narasi yaitu siswa tidak mengetahui apa yang hendak ditulis, hanya menulis judul dan hasilnya siswa tidak dapat menyusun kalimat dengan baik, terdapat pula siswa yang masih menulis kata dengan ejaan yang salah. Selain itu, ditemukan juga beberapa siswa yang mengalami kebingungan dan meminta ada contoh cerita terlebih dahulu dari guru. Hal tersebut dilaksanakan guna memicu dan membantu penuangan ide dari siswa. Namun yang terjadi, siswa lebih banyak menggunakan kalimat yang sama dan hampir $80 \%$ berasal dari contoh yang diberikan oleh guru.

Berdasarkan interview pada tanggal 28 Maret 2018 dengan 17 siswa tentang menulis cerita narasi didapat data, antara lain (1) empat siswa mengatakan bahwa menulis adalah kegiatan yang membosankan dan tidak menyenangkan sehingga mereka tidak suka menulis; (2) delapan siswa mengatakan bahwa menulis sebuah cerita narasi itu sulit; (3) sebanyak tiga siswa mengatakan bahwa mereka menulis sesuai kemampuan dan contoh dari guru; (4) dua siswa lainnya mengatakan bahwa mereka senang menulis karena hobi. Berdasarkan hasil wawancara tersebut diketahui sebanyak 90\% siswa mengatakan bahwa mereka bingung dalam memulai menulis, menentukan kalimat yang harus ditulis terlebih dahulu, bagaimana penyusunan kalimatnya, serta menentukan judul yang akan digunakan.

Berdasarkan permasalahan yang diperoleh melalui pengamatan, dapat diketahui bahwa penyampaian materi yang dilakukan oleh guru masih belum sepenuhnya menggunakan media pembelajaran. Berdasarkan hasil observasi dan wawancara juga ditemukan bahwa siswa merasakan bosan saat pembelajaran menulis sehingga dengan melihat kondisi tersebut, maka perlu adanya inovasi baru yang melibatkan siswa berpikir secara aktif, berinteraksi, melakukan percobaan, menemukan konsep baru, dan menghasilkan suatu karya.

Berdasarkan permasalahan yang terjadi di lapangan dengan didukung beberapa penelitian terdahulu, maka peneliti merancang sebuah penelitian yang berbeda dari penelitian sebelumnya yaitu perpaduan antara model pembelajaran SAVI dengan media CD Interaktif. Hal tersebut sesuai oleh pernyataan (Gaol, Asrin, \& Siregar, 2016) yang mengemukakan bahwa untuk membangkitkan motivasi, perhatian, pemahaman dan prestasi belajar siswa, guru dapat menggunakan model pembelajaran SAVI. Meier (2002) mengemukakan bahwa, model pembelajaran SAVI merupakan langkah-langkah dan aktivitas pembelajaran yang mengolaborasikan aktivitas fisik dengan intelektual yang memanfaatkan semua panca indra. Pada penelitian terdahulu yang pernah dilakukan oleh beberapa penelitian sebelumnya mereka banyak menggunakan model pembelajaran SAVI untuk meningkatkan keterampilan menulis deskripsi, sedangkan model pembelajaran SAVI masih jarang digunakan untuk meningkatkan keterampilan menulis narasi dan belum ada yang mengolaborasikan dengan media CD Interaktif. Meskipun begitu media CD Interaktif pernah dilakukan pada penelitian pengembangan produk untuk membantu siswa dalam belajar menulis. Peneliti terdorong untuk melakukan penelitian yang mengolaborasikan antara model pembelajaran SAVI berbantuan media CD interaktif untuk meningkatkan keterampilan narasi.

Perpaduan ini tidak semata-mata dilakukan tanpa pertimbangan dan kesesuaian model pembelajaran SAVI dengan media CD interaktif. Hal ini didasarkan di dalam model pembelajaran SAVI terdapat unsur somatik, visual, audio, intelektual yang mampu dibantu dengan menggunakan media CD interaktif karena di dalam CD Interaktif ini terdapat unsur somatik, visual, audio, intelektual melalui gambar, video, audio, permainan, petunjuk pembelajaran dan perintah untuk melakukan kegiatan yang mendukung pembelajaran menulis narasi sehingga efektif membantu proses pembelajaran menulis berlangsung. Menurut Geithner \& Pollastro (2015) berpendapat bahwa kegiatan yang dilakukan dalam pembelajaran dengan memusatkan perhatian siswa, dan menjadikan siswa sebagai pusat pembelajaran dapat meningkatkan aktivitas pembelajaran lebih efektif dan kondusif, serta membantu siswa berpikir, berkomunikasi, dan fokus. Berdasarkan penjelasan tersebut, maka peneliti berkeinginan untuk menghadirkan penelitian dengan judul "Peningkatan Keterampilan Menulis Narasi melalui Model Pembelajaran SAVI (Somatic, Auditory, Visual, Intellectual) berbantuan Media CD Interaktif pada Siswa Kelas V di SD Anak Saleh".

\section{METODE}

Penelitian ini menggunakan PTK kolaborasi yang bertujuan memecahkan permasalahan dan membuat aktivitas belajar meningkat di dalam kelas. Selain memecahkan masalah, peneliti juga melakukan perbaikan terhadap permasalahan yang muncul di dalam proses pembelajaran melalui aktivitas guru yang dilakukan sehari-hari di kelas dalam situasi pembelajaran. Kehadiran dan peran di dalam proses penelitian merupakan kunci mutlak untuk mengamati, menggali, menemukan dan memecahkan permasalahan yang ada di lapangan. Penelitian yang dipilih oleh peneliti ini merupakan Penelitian Tindakan Kelas dengan jenis kolaborasi dan partisipasi. Peran peneliti sebagai pengamat, mencari data, menganalisis data, dan pengambilan keputusan (Moleong, 2017). Penelitian ini bertempat di SD Anak Saleh di Jl. Arumba No. 31 Kecamatan Lowokwaru Malang. Penelitian yang dilakukan ini bersifat kolaborasi antara peneliti dengan guru kelas V. Subjek penelitian ini yaitu siswa kelas V SD Anak Saleh sebanyak 28 siswa, terdiri dari 12 laki-laki dan 16 perempuan. Objek penelitian yang diambil berupa proses pembelajaran menulis dan penilaian keterampilan menulis narasi dengan menggunakan model pembelajaran SAVI berbantuan media CD interaktif pada siswa kelas V-A atau V-Tondano di SD Anak Saleh. Dalam 
pengumpulan data ini peneliti menggunakan teknik pengumpulan data yang berupa (1) pengamatan, (2) wawancara, (3) dokumentasi, (4) catatan lapangan, dan (5) metode tes. Teknik analisis data yang digunakan di lapangan merupakan model Miles dan Huberman. Model Miles dan Huberman merupakan suatu cara menganalisis data degan cara, (1) pengurangan dan pemotongan data, (2) pemrosesan data, dan (3) pengambil keputusan (Prayoga, Suwignyo, \& Harsiati, 2017).

\section{HASIL}

Data penelitian ini diperoleh dari kegiatan siswa kelas V SD Anak Saleh Kota Malang dalam membuat cerita. Data ini diambil berdasarkan hasil tes yang dilakukan setiap pertemuan pada siklus I dan II.

Tabel 1. Data Hasil Tes Keterampilan Menulis Narasi Siswa pada Setiap Siklus

\begin{tabular}{|c|c|c|c|c|c|c|c|c|c|c|c|c|c|}
\hline \multirow{3}{*}{ No. } & \multirow{3}{*}{ Nama } & \multicolumn{12}{|c|}{ Skor } \\
\hline & & \multicolumn{6}{|c|}{ Siklus I } & \multicolumn{6}{|c|}{ Siklus II } \\
\hline & & P1 & $\mathbf{P 2}$ & P3 & P4 & Rata-rata & Keterangan & P1 & $\mathbf{P 2}$ & $\mathbf{P 3}$ & P4 & Rata-rata & Keterangan \\
\hline 1 & SISWA 1 & 49 & 44 & 51 & 61 & 51 & Belum Tuntas & 70 & 70 & 73 & 74 & 72 & Tuntas \\
\hline 2 & SISWA 2 & 70 & 69 & 71 & 71 & 70 & Tuntas & 74 & 76 & 80 & 81 & 78 & Tuntas \\
\hline 3 & SISWA 3 & 66 & 70 & 71 & 71 & 70 & Belum Tuntas & 73 & 73 & 76 & 81 & 76 & Tuntas \\
\hline 4 & SISWA 4 & 71 & 71 & 74 & 73 & 72 & Tuntas & 74 & 76 & 79 & 81 & 78 & Tuntas \\
\hline 5 & SISWA 5 & 51 & 53 & 56 & 56 & 54 & Belum Tuntas & 60 & 60 & 63 & 64 & 62 & Belum Tuntas \\
\hline 6 & SISWA 6 & 56 & 61 & 66 & 66 & 62 & Belum Tuntas & 70 & 70 & 71 & 74 & 71 & Tuntas \\
\hline 7 & SISWA 7 & 70 & 70 & 71 & 70 & 70 & Tuntas & 71 & 71 & 74 & 80 & 74 & Tuntas \\
\hline 8 & SISWA 8 & 47 & 50 & 54 & 57 & 52 & Belum Tuntas & 70 & 70 & 70 & 76 & 72 & Tuntas \\
\hline 9 & SISWA 9 & 50 & 60 & 63 & 61 & 59 & Belum Tuntas & 70 & 70 & 73 & 81 & 74 & Tuntas \\
\hline 10 & SISWA 10 & 60 & 60 & 64 & 67 & 63 & Belum Tuntas & 71 & 71 & 74 & 83 & 75 & Tuntas \\
\hline 11 & SISWA 11 & 56 & 59 & 60 & 60 & 59 & Belum Tuntas & 61 & 61 & 63 & 67 & 63 & Belum Tuntas \\
\hline 12 & SISWA 12 & 61 & 64 & 64 & 66 & 64 & Belum Tuntas & 70 & 71 & 70 & 74 & 71 & Tuntas \\
\hline 13 & SISWA 13 & 54 & 56 & 59 & 59 & 57 & Belum Tuntas & 70 & 70 & 70 & 71 & 70 & Tuntas \\
\hline 14 & SISWA 14 & 30 & 39 & 59 & 63 & 48 & Belum Tuntas & 70 & 71 & 71 & 73 & 71 & Tuntas \\
\hline 15 & SISWA 15 & 54 & 60 & 64 & 64 & 61 & Belum Tuntas & 70 & 70 & 73 & 76 & 72 & Tuntas \\
\hline 16 & SISWA 16 & 41 & 47 & 47 & 50 & 46 & Belum Tuntas & 60 & 61 & 63 & 64 & 62 & Belum Tuntas \\
\hline 17 & SISWA 17 & 60 & 60 & 63 & 63 & 62 & Belum Tuntas & 70 & 71 & 70 & 70 & 70 & Tuntas \\
\hline 18 & SISWA 18 & 54 & 59 & 67 & 67 & 62 & Belum Tuntas & 70 & 71 & 76 & 80 & 74 & Tuntas \\
\hline 19 & SISWA 19 & 57 & 59 & 66 & 66 & 62 & Belum Tuntas & 71 & 73 & 76 & 84 & 76 & Tuntas \\
\hline 20 & SISWA 20 & 47 & 53 & 66 & 66 & 58 & Belum Tuntas & 71 & 70 & 74 & 79 & 74 & Tuntas \\
\hline 21 & SISWA 21 & 50 & 56 & 56 & 61 & 56 & Belum Tuntas & 70 & 70 & 70 & 73 & 71 & Tuntas \\
\hline 22 & SISWA 22 & 70 & 71 & 73 & 73 & 72 & Tuntas & 74 & 74 & 77 & 80 & 76 & Tuntas \\
\hline 23 & SISWA 23 & 47 & 50 & 54 & 56 & 52 & Belum Tuntas & 74 & 73 & 73 & 77 & 74 & Tuntas \\
\hline 24 & SISWA 24 & 53 & 54 & 56 & 61 & 56 & Belum Tuntas & 70 & 70 & 76 & 80 & 74 & Tuntas \\
\hline 25 & SISWA 25 & 60 & 61 & 61 & 63 & 61 & Belum Tuntas & 70 & 71 & 71 & 73 & 71 & Tuntas \\
\hline 26 & SISWA 26 & 36 & 60 & 70 & 71 & 59 & Belum Tuntas & 74 & 77 & 79 & 86 & 79 & Tuntas \\
\hline 27 & SISWA 27 & 27 & 51 & 63 & 64 & 51 & Belum Tuntas & 69 & 70 & 70 & 80 & 72 & Tuntas \\
\hline 28 & SISWA 28 & 50 & 59 & 61 & 61 & 58 & Belum Tuntas & 69 & 70 & 71 & 73 & 71 & Tuntas \\
\hline
\end{tabular}

Dari data tabel nilai keterampilan menulis narasi siswa kelas $\mathrm{V}$ di atas, terlihat bahwa terdapat perbedaan yang signifikan antar siklus. Pada siklus I yang dilakukan dalam empat pertemuan, mendapatkan hasil bahwa terdapat 4 dari 28 siswa yang tuntas memenuhi nilai KKM, yaitu 70. Pada siklus ke II dilakukan empat pertemuan mendapatkan hasil bahwa terdapat 25 dari 28 siswa yang tuntas memenuhi nilai KKM, yaitu 70. Dari siklus I terdapat 14,28\% yang tuntas memenuhi nilai KKM yaitu 70, sedangkan pada siklus II terdapat $89,28 \%$ yang tuntas memenuhi nilai KKM yaitu 70. Dengan demikian, dari siklus I ke siklus II mengalami kenaikan persentase sebanyak $75 \%$ siswa yang mengalami kenaikan pada hasil tulisan cerita mereka yang sesuai dengan nilai KKM yaitu 70. Dari hasil tersebut dapat kita ambil kesimpulan bahwa terdapat peningkatan di setiap siklusnya setelah digunakan model pembelajaran SAVI berbantuan media CD Interaktif untuk membantu siswa dalam keterampilan menulis narasi.

Berdasarkan pengamatan yang dilakukan pada saat pembelajaran menulis narasi ditemukan beberapa permasalahan yang terjadi ketika pembelajaran siklus I sehingga untuk penelitian di siklus II terdapat perbaikan dalam beberapa hal sebagai berikut. Pertama, pada siklus I ditemukan beberapa siswa yang melakukan kesalahan dalam penulisan kata ejaan sesuai EBI, tanda baca, penggunaan huruf kapital, alur, dan keluasan pemakaian kosakata. Oleh karena itu, guru melakukan perbaikan pada siklus II dengan cara menyampaikan kesalahan yang dilakukan siswa pada siklus I dan guru mengulang kembali materi kepenulisan pada siswa sehingga tidak terulang kembali kesalahan pada siklus II. Kedua, terdapat enam siswa yang masih merasa bingung untuk memulai menulis. Permasalahan tersebut terjadi karena saat kegiatan siswa itu senang mengobrol dengan temannya. Dalam hal ini guru perlu melakukan perbaikan pada siklus II untuk memusatkan perhatian siswa terhadap perintah, petunjuk, dan penjelasan yang disampaikan oleh guru dan teman sebayanya. Ketiga, sebagian siswa belum berani untuk 
mengungkapkan gagasan dan aktif saat pembelajaran. Kemudian guru dapat melakukan perbaikan pada siklus II dengan memotivasi siswa serta pemberian reward kepada siswa yang berani dan percaya diri menyampaikan pendapatnya sehingga siswa lebih percaya diri. Cara lain yang dapat dilakukan guru yaitu meminta siswa yang kurang percaya diri untuk berinteraksi dan menyampaikan pendapatnya untuk melatih kepercayaan diri siswa.

Tabel 2. Rekapitulasi Keterampilan Menulis Narasi Siswa di Setiap Indikator

\begin{tabular}{clcccc}
\hline Indikator & \multicolumn{1}{c}{ Deskripsi } & Siklus I & Kategori & Siklus II & Kategori \\
\hline 1 & Kesesuaian isi tulisan dengan judul cerita narasi & 67 & $\mathrm{~B}$ & 89 & $\mathrm{~A}$ \\
2 & Kejelasan latar cerita & 59 & $\mathrm{C}$ & 76 & $\mathrm{~B}$ \\
3 & Kejelasan alur cerita (kelogisan urutan cerita narasi) & 52 & $\mathrm{C}$ & 71 & $\mathrm{~B}$ \\
4 & Pengorganisasian bagian pembuka, isi, dan penutup. & 54 & $\mathrm{C}$ & 67 & $\mathrm{~B}$ \\
5 & Variasi bentuk kata (dasar, berimbuhan, majemuk) & 54 & $\mathrm{C}$ & 68 & $\mathrm{~B}$ \\
6 & Variasi jenis kata (benda, kerja, sifat, tugas) & 55 & $\mathrm{C}$ & 68 & $\mathrm{~B}$ \\
7 & Keluasan pemakaian kosakata & 74 & $\mathrm{~B}$ & 73 & $\mathrm{~B}$ \\
8 & Variasi bentuk kalimat (tunggal, majemuk, campuran) & 51 & $\mathrm{C}$ & 66 & $\mathrm{~B}$ \\
9 & Kejelasan fungsi-fungsi kalimat (subjek, predikat, objek) & 52 & $\mathrm{C}$ & 68 & $\mathrm{~B}$ \\
10 & Kehematan penggunaan kata-kata & 57 & $\mathrm{C}$ & 70 & $\mathrm{~B}$ \\
11 & Kesesuaian bentukan kata ulang dengan kaidah tata bahasa & 52 & $\mathrm{C}$ & 67 & $\mathrm{~B}$ \\
12 & Kesesuaian penulisan kata dengan kaidah EBI & 79 & $\mathrm{~B}$ & 81 & $\mathrm{~A}$ \\
13 & Kesesuaian penulisan huruf besar dengan kaidah EBI & 49 & $\mathrm{C}$ & 68 & $\mathrm{~B}$ \\
14 & Kesesuaian penulisan tanda baca dengan kaidah EBI & 77 & $\mathrm{~B}$ & 79 & $\mathrm{~B}$ \\
\hline
\end{tabular}

Dari data rekapitulasi terlihat bahwa siswa mengalami peningkatan secara signifikan dibandingkan pada siklus I. Hal tersebut didukung adanya perbaikan dan peningkatan pada siklus II dalam kegiatan proses pembelajaran, yaitu (1) perhatian siswa yang terpusat kepada guru saat penjelasan materi, siswa terlibat aktif berinteraksi dengan guru, siswa fokus pada kegiatan pembelajaran; (2) keaktifan siswa dalam menggali pengetahuan dan informasi untuk menentukan topik pada cerita narasi yang dibuat; (3) keberagaman judul cerita yang terlihat dari hasil menulis siswa; (4) kerangka cerita yang dibuat secara utuh di dalam tulisan; (5) perbaikan dalam hal menulis ejaan sesuai EBI.

\section{PEMBAHASAN}

Dari hasil temuan pada saat penelitian, guru kelas V di SD Anak Saleh Kota Malang sudah membuat RPP secara madiri, guru menyesuaikan dengan tingkat perkembangan perkembangan dan lingkungan sekitar. Hal ini sesuai dengan Kunandar (2014) yang menyatakan bahwa "Pembuatan RPP yang berpedoman pada Standar Kompetensi dilakukan sebelum proses pembelajaran dilaksanakan". RPP ini sangat efektif untuk digunakan pada kondisi kegiatan pembelajaran, namun tentunya RPP yang disusun berpatok pada KI dan KD yang telah tersedia.

Kegiatan pendahuluan, guru sudah menuliskan kegiatan apersepsi, informasi materi, serta informasi tujuan. Sebagaimana diungkapkan oleh Hooper et al., (2013) bahwa sebelum memulai pembelajaran guru harus mengecek kesiapan siswa dalam belajar, mengomunikasikan tujuan pembelajaran, serta menyampaikan garis besar materi dan kegiatan yang dilakukan oleh siswa selama pembelajaran berlangsung. Berdasarkan ungkapan ini, kegiatan pendahuluan guru yang ditulis dalam RPP sudah sesuai. Akan tetapi, masih ada beberapa ketidaksesuaian yakni guru masih belum merincikan kegiatan yang akan dilakukan pada kegiatan pendahuluan.

Guru melakukan kegiatan inti dengan menuliskan pembelajaran tematik dengan langkah pada SAVI dibantu dengan saintifict approach pada aktivitas pengamatan, bertanya jawab, pengumpulan informasi, mencoba sesuatu, menalar dan mengomunikasikan. Hal ini sudah sesuai dengan Kementerian Pendidikan dan Kebudayaan (2013a) bahwa "Pendekatan saintifik terdiri atas aktivitas mengamati, menanya, mencoba, menalar, dan mengomunikasikan.” Selain itu, pada kegiatan inti guru juga sudah mencantumkan proses pembelajaran dengan menggunakan model pembelajaran SAVI. Hal ini sesuai dengan pendapat Zulfahita (2017) bahwa "Model pembelajaran SAVI dapat diintegrasikan dengan pendekatan saintifik dengan kegiatan somatik berupa tindakan, auditori berupa mendengar, visual berupa pengamatan, dan intelektual berupa kegiatan berpikir.” Pada kegiatan ini, siswa dapat bereksplorasi secara mandiri dengan menggunakan media CD interaktif yang terdapat video, cerita pendek, musik, dan permainan. Menurut Mcgrail, Mcgrail, \& Rieger (2016) berpendapat bahwa pengalaman siswa akan terbentuk sangat baik dan bermakna apabila di dalam pembelajaran siswa dapat belajar dengan dibantu oleh video, gambar, cerita pendek, instrumen musik, permainan, dan latihan-latihan.

Kegiatan penutup berisikan aktivitas menyimpulkan bersama antara guru dan siswa. Selain itu, guru juga memberikan tindak lanjut berupa tugas yang dikerjakan di rumah baik kelompok ataupun individu. Hal ini sesuai dengan pernyataan Ramadania \& Winda (2017) bahwa "kegiatan penutup meliputi kegiatan yang berupa mengevaluasi aktivitas belajar mengajar yang telah berlangsung, melakukan kegiatan tindak lanjut yang meliputi pemberian tugas terutama yang berkaitan dengan materi yang kurang dipahami, dan memberikan umpan balik terhadap hasil yang diperoleh siswa. Pada penilaian yang dibuat, guru sudah menyesuaikannya dengan penilaian autentik. Guru sudah menyesuaikan intrumen serta jenis penilaian yang digunakan dengan tujuan pembelajaran yang ingin dicapai. Secara keseluruhan, RPP yang dibuat oleh guru sudah menerapkan 
prinsip-prinsip pengembangan RPP yang baik. Sebagaimana dinyatakan oleh (Majid, 2014) bahwa terdapat beberapa prinsip dalam pengembangan RPP, antara lain memperhatikan perbedaan individu siswa, mendorong partisipasi siswa, pemberian umpan baik positif, penguatan, pengayaan dan remidial, mengembangkan kemampuan siswa dalam membaca dan menulis, serta menerapkan teknologi informasi dan komunikasi.

Berdasarkan pengamatan pada kondisi awal dapat diketahui bahwa dalam penggunaan media pembelajaran dan model pembelajaran yang dilakukan oleh guru kurang maksimal. Sehingga dengan adanya permasalahan berupa siswa merasa kesulitan dalam memahami materi pelajaran, proses pembelajaran di dalam kelas tidak efektif guru kurang bereksperimen memunculkan suasana belajar yang baru bagi siswa sehingga peneliti memberikan solusi untuk menggunakan model pembelajaran SAVI untuk memperbaiki permasalahan pada kegiatan menulis. Dalam hal ini sesuai dengan konsep dasar PTK yang dikemukakan oleh (Arikunto, 2015) bahwa "penelitian tindakan kelas ini dilakukan secara berkesinambungan dan kemudian diamati secara berkala untuk menganalisa tindakan yang dilakukan sehingga mampu memberikan keputusan pada tindakan yang tepat."

Pelaksanaan pada siklus pertama dan kedua dalam kegiatan pendahuluan, guru memulai pembelajaran dengan berinteraksi dengan siswa untuk mengukur sejauh mana siswa memiliki pengalaman pribadi yang dilakukan bersama keluarga. Secara bergantian siswa menceritakan pengalaman pribadi yang pernah dirasakan. Selain itu, guru juga menjelaskan kompetensi yang perlu dicapai, materi yang akan dipahami, dan aktivitas selama pembelajaran. Hal ini sesuai dengan yang diungkapkan oleh Wijayanti, Gipayana, \& Muhardjito (2018) bahwa dalam kegiatan awal guru menumbuhkan kesiapan belajar pada siswa, mengajukan pertanyaan-pertanyaan tentang materi dan tujuan yang akan diperoleh dalam pembelajaran, serta menyampaikan beberapa kegiatan yang akan dilakukan oleh siswa selama pembelajaran. Kemudian pada tahap inti guru memaparkan tentang keterampilan menulis narasi. Pemberian contoh dengan membacakan cerita narasi oleh guru. Penjelasan materi tentang menulis narasi dan peninggalan sejarah kerajaan islam di Indonesia. Pada kegiatan ini siswa diarahkan untuk mencari materi tentang tahap-tahap menulis, dan cara membuat karangan narasi yang diperoleh dengan melibatkan alat indra, yang sesuai dengan menggunakan model pembelajaran SAVI yaitu dengan cara melihat, mendengar, gerak, dan berpikir. Setelah itu siswa diminta untuk menulis cerita narasi dengan berbagai tema. Hal ini sesuai dengan tahapan pada model pembelajaran SAVI menurut (Meier, 2002) bahwa model pembelajaran SAVI merupakan langkah-langkah dan aktivitas pembelajaran yang mengolaborasikan aktivitas fisik dengan intelektual yang memanfaatkan semua panca indra.

Di akhir pembelajaran, guru dan siswa berdiskusi tentang hambatan yang dialami siswa, memberikan tindak lanjut, dan memberikan umpan balik. Hal ini sesuai dengan pendapat (Prastowo, 2014) yaitu "sifat dari kegiatan penutup adalah untuk menenangkan." Oleh karena itu, guru memberikan pendapat tentang kegiatan pembelajaran yang berlangsung, memberikan tindak lanjut mengenai penugasan, terutama yang berkaitan dengan materi yang kurang dipahami dan menyampaikan rencana kegiatan pembelajaran untuk pertemuan berikutnya.

\section{SIMPULAN}

Rendahnya hasil belajar siswa dapat ditingkatkan dengan penggunaan model pembelajaran SAVI berbantuan media CD interaktif sehingga siswa dapat melakukan penulisan narasi dengan lebih baik dari sebelum dilakukan tindakan. Penerapan model pembelajaran SAVI berbantuan media CD interaktif dapat digunakan oleh guru dalam menyampaikan materi keterampilan menulis. Dengan penerapan model pembelajaran SAVI berbantuan media CD interaktif diharapkan dapat membantu siswa meningkatkan keterampilan menulis narasi dan dijadikan rujukan untuk penelitian yang akan datang. Selain itu, penerapan model pembelajaran SAVI berbantuan media CD interaktif dapat dijadikan sebagai bahan acuan penelitian dalam keterampilan menulis lainnya.

\section{DAFTAR RUJUKAN}

Abdul, M. (2014). Strategi Pembelajaran (2nd ed.). Bandung: Remaja Rosadakarya.

Arikunto, S. (2015). Penelitian Tindakan Kelas (Edisi Revisi). Bandung: Bumi Aksara.

Gaol, H. A. L., \& Siregar, M. (2016). The Effect of Applying Somatic Auditory Visual Intellectual (SAVI) Method on Students Achievement in Writing Report Text. Transform Journal of English Language Teaching and Learning, 3(4), 45-46.

Geithner, C. A., \& Pollastro, A. N. (2015). Constructing Engaged Learning in Scientific Writing: Implementation and assessment of a blended pedagogical approach. Journal of Applied Research in Higher Education, 7(2), $292-307$. https://doi.org/10.1108/JARHE-04-2014-0053

Gipayana, M. (2004). Pengajaran Literasi dan Penilaian Portofolio dalam Konteks Pembelajaran Menulis di SD. Jurnal Ilmu Pendidikan, 11(1), 1-12. https://doi.org/10.17977/JIP.V11I1.87

Hooper, S. R., Costa, L. J. C., McBee, M., Anderson, K. L., Yerby, D. C., Childress, A., \& Knuth, S. B. (2013). A written language intervention for at-risk second grade students: A randomized controlled trial of the process assessment of the learner lesson plans in a tier 2 response-to-intervention (RtI) model. Annals of Dyslexia, 63(1), 44-64. https://doi.org/10.1007/s11881-011-0056-y

Kementerian Pendidikan dan Kebudayaan. (2013). Kerangka Dasar Kurikulum 2013. Retrieved from http://bsnpindonesia.org/2013/06/20/permendikbud-tentang-kurikulum-tahun-2013/ 
Kunandar. (2014). Penilaian Autentik (Penilaian Hasil Belajar Peserta Didik Berdasarkan Kurikulum 2013) (1st ed.). Jakarta: Rajagrafindo Persada.

Mcgrail, E., Mcgrail, J. P., \& Rieger, A. (2016). Writing Instruction to Support Literacy Success, 7. https://doi.org/10.1108/S2048-045820177

Meier, D. (2002). The Accelerated Learning. Bandung: Kaifa.

Moleong, L. J. (2017). Metode Penenlitian Kualitatif (37th ed.). Bandung: PT. Remaja Rosdakarya.

Mudiono, A. (2010). Pengembangan Bahan Pembelajaran Bahasa Indonesia Sekolah Dasar. Malang: Fakultas Ilmu Pendidikan Universitas Negeri Malang.

Murcia, M. C., \& Olshtain, E. (2000). Discourse and Context in Language Teaching. New York: Cambridge University Press.

Prastowo, A. (2014). Pengembangan Bahan Ajar Tematik (1st ed.). Jakarta: Kencana Prenada Groups.

Prayoga, R. W., Suwignyo, H., \& Harsiati, T. (2017). Peningkatan Keterampilan Menulis Cerita Berbantuan Media Buku Cerita Anak. Jurnal Pendidikan: Teori, Penelitian, dan Pengembangan, 2(11), 1498-1503.

Ramadania, F., \& Winda, N. (2017). Indonesian Language Skills through Somatic, Auditory, Visually, Intellectually Learning Model. Atlantis Press, 100, 341-344.

Wijayanti, R., \& Gipayana, M., \& Muhardjito. (2018). The Implementation of Scientific Learning Approach Six Thinking Hats Model to Enhance Students' Thematic Learning Quality for The 5 th Grader of Elementary School. Jurnal Pendidikan: Teori, Penelitian, dan Pengembangan, 3(8), 1059-1067.

Wulandari, R. T. (2014). Penerapan Model SAVI (Somatis, Auditori, Visual, Intelektual) dalam Pembelajaran Menulis Karangan Narasi. Bahtera Bahasa: Antologi Pendidikan Bahasa dan Sastra Indonesia, 1, 1-9.

Yafi, M. A., Santoso, A., \& Mudiono, A. (2017). Peningkatan Keterampilan Menulis Narasi melalui Penerapan Model STAD Berbantu Media Gambar Seri pada Siswa SD. Jurnal Pendidikan: Teori, Penelitian, dan Pengembangan, 2(11), 15041508.

Zulfahita. (2017). Optimization Approach for Use SAVI to Learning Outcomes Creativity Writing Poetry of Learning Techniques Trough Direct Object. ADRI International Journal of Language, Literature and Culture, 1, 24-27. 